\title{
Quality of fresh and aged meat from lambs fed peanut meal and glycerin ${ }^{1}$
}

\section{Qualidade das carnes fresca e maturada de cordeiros alimentados com farelo de amendoim e glicerina}

\author{
Roberta de Lima Valença ${ }^{2 *}$; Américo Garcia da Silva Sobrinho3; Eliéder Prates \\ Romanzini ${ }^{4}$; Nomaiací de Andrade ${ }^{5}$; Thiago Henrique Borghi'; Nivea Maria \\ Brancacci Lopes Zeola ${ }^{6}$; Mikaele Alexandre Pereira ${ }^{7}$; Luis Gabriel Alves Cirne ${ }^{8}$
}

\begin{abstract}
Were evaluated the microbiological and physicochemical characteristics of fresh and aged semimembranosus muscle from 40 uncastrated male Ile de France lambs with $17.15 \pm 1.56 \mathrm{~kg}$ of initial body weight. Treatments involved fresh and meat aged for 14 days at $4{ }^{\circ} \mathrm{C}$ from lambs receiving four diets, as follows: control; PM - diet with $20 \%$ peanut meal replacing soybean meal; $\mathrm{G}$ - diet with $25 \%$ glycerin replacing corn; and PMG - diet with $10 \%$ peanut meal and $12.5 \%$ glycerin. The forage:concentrate ratio was 40:60, and corn silage was used as roughage. The diets had similar values of crude protein and metabolizable energy (17.47\% and $2.72 \mathrm{Mcal} \mathrm{kg/dry} \mathrm{matter).} \mathrm{A} \mathrm{completely} \mathrm{randomized} \mathrm{design} \mathrm{was}$ adopted in a $4 \times 2$ factorial arrangement (four diets $\times$ fresh and aged meat). Diets and aging did not favor the development of microorganisms in the meat. There was an interaction effect between diets and aging for $\mathrm{pH}$, color, cooking weight loss (CL), and shear force (SF). The fresh meat from animals fed $\mathrm{G}$ was lighter compared with the meat from those consuming PM and PMG (lightness of 38.45, 36.26 and 37.88 respectively). Aging increased lightness (37.63 to 40.87 ), red intensity (15.12 to 15.93 ), yellow intensity (2.48 to 3.42 ) and $\mathrm{CL}$ (23.84 to $32.59 \%)$, reduced $\mathrm{pH}$ (5.66 to 5.45), water holding capacity $(61.85$ to $58.87 \%)$ and SF (22.60 to $16.95 \mathrm{~N})$. By-products from biodiesel and peanut production can be used to replace corn and soybean meal in diets for lambs without compromising their meat quality.

Key words: Aged meat. Biodiesel. By-products. Meat quality. Sheep.
\end{abstract}

1 Parte da Tese de Doutorado da primeira autora pelo Programa de Pós-Graduação em Zootecnia, Faculdade de Ciências Agrárias e Veterinárias, Universidade Estadual Paulista, Unesp, Jaboticabal, SP, Brasil.

2 Pós-Doutoranda, Universidade Federal Rural de Pernambuco, UFRPE, Garanhuns, PE, Brasil. E-mail: robertalimav@hotmail. com

3 Prof., Departamento de Zootecnia, Faculdade de Ciências Agrárias e Veterinárias, Universidade Estadual Paulista, Unesp, Jaboticabal, SP, Brasil. E-mail: americo.s.sobrinho@unesp.br

4 Discente, Curso de Doutorado, Programa de Pós-Graduação em Zootecnia, Unesp, Jaboticabal, SP, Brasil. E-mail: elieder. romanzini@gmail.com

5 Drs. em Zootecnia, Faculdade de Ciências Agrárias e Veterinárias, Universidade Estadual Paulista, Unesp, Jaboticabal, SP, Brasil. E-mail: nomaiaci_andrade@yahoo.com.br; thiagoborghi@zootecnista.com.br

6 Pesquisadora, Faculdade de Ciências Agrárias e Veterinárias, Universidade Estadual Paulista, Unesp, Jaboticabal, SP, Brasil. E-mail: nivea.brancacci@ig.com.br

7 Dra . em Ciência Animal, Universidade de São Paulo, USP, Pirassununga, SP, Brasil. E-mail: mikaeleapereira@gmail.com

8 Prof., Universidade Federal do Oeste do Pará, UFOPA, Santarém, PA, Brasil. E-mail: 1gabrielcirne@hotmail.com

* Author for correspondence 


\section{Resumo}

Foram avaliadas as características microbiológicas e físico-químicas de músculos semimembranosos frescos e maturados provenientes de 40 cordeiros Ile de France machos não castrados, com 17,15 kg de peso corporal inicial \pm de $1,56 \mathrm{~kg}$. Os tratamentos envolveram carnes de cordeiros frescas e maturadas por 14 dias a $4^{\circ} \mathrm{C}$ e alimentados com quatro dietas: C - dieta controle; FA - dieta com $20 \%$ de farelo de amendoim em substituição ao farelo de soja; $\mathrm{G}$ - dieta com $25 \%$ de glicerina em substituição ao milho e FAG: dieta com $10 \%$ de farelo de amendoim e $12,5 \%$ de glicerina. A relação volumoso:concentrado foi de 40:60 e silagem de milho utilizada como volumoso. As dietas possuíam valores semelhantes de proteína bruta e energia metabolizável (17,47\% e 2,72 Mcal kg de matéria seca). Adotou-se delineamento inteiramente casualizado em esquema fatorial 4 × 2 (quatro dietas e carne fresca e maturada). As dietas e a maturação não favoreceram o desenvolvimento de microrganismos na carne. Houve interação entre dietas e maturação para $\mathrm{pH}$, cor, perda de peso na cocção (PPC) e força de cisalhamento (FC). A carne fresca dos animais alimentados com a dieta $\mathrm{G}$ foi mais clara em relação a carne daqueles alimentados com as dietas FA e FAG (luminosidade de 38,45, 36,21 e 37,88 respectivamente). A maturação elevou a luminosidade $(37,63$ para 40,87), intensidade de vermelho $(15,12$ para 15,93$)$, intensidade de amarelo $(2,48$ para 3,42$)$ e PPC $(23,84$ para $32,59 \%)$. Reduziu o $\mathrm{pH}(5,66$ para 5,45$)$, CRA $(61,85$ para $58,87 \%)$ e FC (22,60 para $16,95 \mathrm{~N})$. Os coprodutos do biodiesel e do amendoim podem ser utilizados em substituição ao milho e ao farelo de soja na dieta de cordeiros, sem comprometer de forma negativa a qualidade da carne.

Palavras-chave: Biodiesel. Carne maturada. Coprodutos. Ovino. Qualidade da carne.

\section{Introduction}

Because of the high costs of feeding lambs finished in feedlot systems, producers seek alternative food sources to minimize expenditures, especially potential substitutes to soybean meal and corn, which are high-priced ingredients and the major constituents of concentrates.

By-products have stood out as a food alternative for ruminants. In this regard, as a protein source, the peanut meal (ALETOR; OJELABI, 2007; EZEQUIEL et al., 2011) is a possible substitute to the traditional soybean meal (SILVA et al., 2016), while glycerin is a potential substitute to corn due to the energy properties (FAVARO et al., 2016).

The use of these by-products can be inserted in the meat production chain as cheaper sources of energy and protein and as an environmentalfriendly destination of the waste generated by the agricultural and biodiesel industries, which have grown annually because of governmental incentives to produce this fuel. The peanut meal is a by-product derived from oil extraction, whereas glycerin originates from biodiesel production, accounting for $10 \%$ of all biodiesel produced (DASARI et al., 2005; JOHNSON; TACONI, 2007).

The consumption of refrigerated vacuumpacked meat is a growing trend in the national scenario, particularly valued meats such as lamb. The permanence of meat in vacuum packages at temperatures higher than the freezing point favors the aging process, which can result in an increase in tenderness and flavor (BAWCOM et al., 1995). The aging process provides organoleptic benefits to the meat, although studies characterizing pathogenic microorganisms present in this product during storage are still limited.

Research addressing feed substitutes for ruminants usually focuses on traditional ingredients such as corn and soybean, and reports of the simultaneous replacement of these ingredients are rare. Therefore, the present study was carried out to evaluate the microbiological stability and quality of fresh and aged meat from Ile de France lambs fed peanut meal and glycerin in an exclusive and simultaneous substitution of soybean meal and corn. 


\section{Materials and Methods}

The study complied with the ethical principles of animal experimentation adopted by the National Council for the Control of Animal Experimentation (CONCEA) and was approved by the Committee of Ethics in Animal Use (CEUA) of the Faculty of Agricultural and Veterinary Sciences (FCAV) of the São Paulo State University (Unesp) (no. 022014/13).

The experiment was carried out in Jaboticabal SP, Brazil (21 ${ }^{\circ} 15^{\prime} 22^{\prime \prime} \mathrm{S}$ and 48 $18^{\circ}$ '58” W; $595 \mathrm{~m}$ asl), involving 40 uncastrated male Ile de France lambs with $17.15 \pm 1.56 \mathrm{~kg}$ initial body weight. While they were breastfed, the lambs were kept in a semiextensive system with Tifton 85 grass (Cynodon spp.), with ad libitum concentrate supply (15.35\% crude protein and 2.85 Mcal metabolizable energy $\mathrm{kg}^{-1}$ [dry matter (DM) basis]) in creep feeders. After approximately 60 days of age, the lambs were identified, dewormed, vaccinated against clostridial diseases, and supplemented with iron and vitamins A, D, and E, so were then housed in individual pens measuring approximately $1 \mathrm{~m}^{2}$, with slatted and suspended floor, equipped with individual feeders and drinkers and installed in a covered shed.

Lambs were randomly distributed into experimental groups according to the following diets: control, containing a standard concentrate; PM - concentrate with $20 \%$ peanut meal; $\mathrm{G}$ - concentrate with 25\% glycerin; and PMG - concentrate with $10 \%$ peanut meal and $12.5 \%$ glycerin (percentages of inclusion on a DM basis) (Table 1). The diets contained similar protein $(17.47 \%)$ and energy (2.72 Mcal metabolizable energy $\mathrm{kg}^{-1}$ [DM basis]) contents, calculated to meet the requirements as recommended by the NRC (2007) for weaned lambs, to provide an average weight gain of $300 \mathrm{~g}$ day $^{-1}$. A 40:60 forage:concentrate ratio was used, with corn silage as the roughage.

Table 1. Centesimal composition of ingredients and chemical composition of experimental diets.

\begin{tabular}{lcccc}
\hline \multirow{2}{*}{ Composition } & \multicolumn{4}{c}{ Experimental diet } \\
\cline { 2 - 4 } & $\mathrm{C}$ & $\mathrm{PM}$ & $\mathrm{G}$ & PMG \\
\hline Ingredient (\%DM) & & & \\
$\quad$ Corn silage & 40.00 & 40.00 & 40.00 & 40.00 \\
Crude glycerin & 0.00 & 0.00 & 25.00 & 12.50 \\
Peanut meal & 0.00 & 20.00 & 0.00 & 10.00 \\
Soybean meal & 21.00 & 0.00 & 32.35 & 16.00 \\
Ground corn & 36.25 & 37.00 & 0.00 & 18.66 \\
Dicalcium phosphate & 1.45 & 1.90 & 1.50 & 1.70 \\
Calcitic limestone & 0.30 & 0.10 & 0.15 & 0.14 \\
Mineral-vitamin supplement & 1.00 & 1.00 & 1.00 \\
Chemical composition & 1.00 & 1.00 & \\
Dry matter $^{2}$ & & & 65.37 & 65.79 \\
Organic matter $^{3}$ & 65.41 & 66.21 & 92.29 & 93.07 \\
Crude protein $^{3}$ & 93.58 & 93.86 & 17.26 & 17.46 \\
Ether extract $^{3}$ & 17.37 & 17.78 & 1.77 & 2.86 \\
Mineral matter $^{3}$ & 4.02 & 3.94 & 7.71 & 6.93 \\
Neutral detergent fiber $^{3}$ & 6.42 & 6.14 & 21.37 & 25.79 \\
& 26.39 & 30.20 & & continue
\end{tabular}


continuation

\begin{tabular}{lcccc} 
Acid detergent fiber $^{3}$ & 14.87 & 16.53 & 13.05 & 14.78 \\
Total carbohydrates $^{3}$ & 72.19 & 72.14 & 73.26 & 72.75 \\
${\text { Metabolizable energy }\left(\mathrm{Mcal} \mathrm{kg}^{-1} \mathrm{DM}\right)^{4}}^{2}$ & 2.80 & 2.74 & 2.64 & 2.68 \\
\hline
\end{tabular}

DM - dry matter; ME - metabolizable energy; DE - digestible energy.

$\mathrm{C}$ - roughage + standard concentrate; PM - roughage + concentrate with $20 \%$ peanut meal; G - roughage + concentrate with $25 \%$ glycerin; PMG - roughage + concentrate with $10 \%$ peanut meal and $12.5 \%$ glycerin, (inclusion percentages on a dry-matter basis).

${ }^{1}$ Provides per kg: calcium - 120 g; chlorine - 90 g; sodium - 62 g; magnesium - 54 g; phosphorus - 50 g; sulfur - 34 g; zinc - 1,600 mg; manganese - 1,500 mg; iron - 1,064 mg, fluorine (max) - 730 mg; copper - 50 mg; iodine - 25 mg; selenium - 20 mg; cobalt - 10 mg; vitamin A - 100,000 IU; vitamin D3 - 40,000 IU; vitamin E - 600 IU.

${ }^{2}$ Values expressed in $\%$.

$3 \% \mathrm{DM}$.

${ }^{4} \mathrm{ME}=0.82 \times \mathrm{DE}(\mathrm{SNIFFEN}$ et al., 1992).

To determine the chemical composition of the diets, samples were dried in a forced-air oven at 55 ${ }^{\circ} \mathrm{C}$ for $72 \mathrm{~h}$. After drying, samples were ground in a knife mill (Wiley, AH Thomas, Philadelphia, PA, USA), with a $1 \mathrm{~mm}$ sieve and analyzed to determine the dry matter (AOAC, 1995), mineral matter (MM) and ether extract (EE) (AOAC, 1990) contents. The neutral (NDF) and acid (ADF) detergent fiber levels were determined according to the method described by Van Soest et al. (1991), using the ANKOM 2000 fiber analyzer (ANKOM Technologies, Macedon, NY, USA) and adding heat-stable alpha-amylase in the NDF.

The organic matter content was obtained by difference (100 - mineral matter), and the metabolizable energy (ME) was calculated from the digestible energy (DE), as established by the NRC (2007), according to the following equation: $\mathrm{ME}=\mathrm{DE} \times 0.82$. To obtain the $\mathrm{DE}$, the gross energy (GE) was determined by the combustion of samples in adiabatic bomb calorimeter (PARR Instruments). The obtained values were inserted into the following equation: $\mathrm{DE}=\mathrm{GE}-(\mathrm{GE} \times$ $20 \%$ ). Total carbohydrates (TC) were calculated by the following equation: $\mathrm{TC}=100-(\%$ crude protein $+\% \mathrm{EE}+\%$ mineral matter). Glycerin (83.9\% glycerol; $12.1 \%$ water; $3.79 \%$ mineral salts; and $0.28 \%$ ether extract), provided by the Cargil Agrícola S. A. company (Três Lagoas, MS, Brazil), was weighed and mixed with the concentrate at the moment of feeding. The peanut meal, provided by the Sementes Esperança company (Jaboticabal, SP, Brazil), was previously mixed with the concentrate. The diets were provided to the animals at $07.00 \mathrm{~h}$ and $17.00 \mathrm{~h}$, to allow a minimum of $10 \%$ of leftovers from the previous day.

Once the animals reached $32 \pm 0.662 \mathrm{~kg}$, they were deprived of solid feeds for 16 hours before humane slaughter. After the animals were stunned by a TEC 10PC concussion pistol, the jugular veins and carotid arteries were sectioned for bleeding, followed by evisceration and removal of the head and extremities of the limbs. Carcasses were kept in a cold room at $6{ }^{\circ} \mathrm{C}$ for $24 \mathrm{~h}$, hung by the gastrocnemius tendons on appropriate hooks, with a $17 \mathrm{~cm}$ distance between extremities.

Twenty-four hours after slaughter, the carcasses were sectioned lengthwise and the semimembranosus muscles were removed from the half-carcasses. The muscles from the left half of the carcasses were subjected to microbiological analyses (total and thermotolerant coliforms, coagulase-positive Staphylococcus, and Salmonella spp.) and physicochemical analyses $(\mathrm{pH}$, color, water-holding capacity [WHC], cooking weight loss [CL], and shear force [SF]). The muscles from the right side were vacuum-packed and aged in a B.O.D. (Biochemical Oxygen Demand) incubator for 14 days at $4{ }^{\circ} \mathrm{C}$; thereafter, they underwent 
the same analyses performed on the left side of semimembranosus muscles.

Microbiological analyses were performed according to Ordinance no. 12 of the Ministry of Agriculture, Livestock and Food Supply, published on September 172001.

For the count of total coliforms, thermotolerant coliforms, and coagulase-positive Staphylococcus, $25 \mathrm{~g}$ of each sample fresh and aged were aseptically weighted, ground, and diluted in $225 \mathrm{~mL} 0.1 \%$ peptone water. The obtained aliquot corresponded to a $10^{-1}$ dilution, from which dilutions up to $10^{-3}$ were obtained.

Coliforms were identified by the multiple-tube method, in triplicate, using $10^{-2}$ and $10^{-3}$ decimal dilutions. The presumptive test was carried out in Durham tubes containing lactose broth that were inverted and incubated at $37{ }^{\circ} \mathrm{C}$ for $48 \mathrm{~h}$. The confirmatory test was performed in EC (Escherichia coli) broth and brilliant green broth and incubated at $45.5^{\circ} \mathrm{C}$ for $48 \mathrm{~h}$ and $37{ }^{\circ} \mathrm{C}$ for $48 \mathrm{~h}$, respectively. The $10^{-2}$ and $10^{-3}$ dilutions were streaked onto Baird Parker agar and incubated at $37{ }^{\circ} \mathrm{C}$ for $48 \mathrm{~h}$ to identify Staphylococcus spp. Typical colonies were Gram-stained and subjected to catalase and coagulase tests.

To identify Salmonella spp., $25 \mathrm{~g}$ of each sample were aseptically weighted, ground and diluted in $225 \mathrm{~mL}$ lactose broth and incubated at $37{ }^{\circ} \mathrm{C}$ for 18 h. Subsequently, $10 \mathrm{~mL}$ from the tubes presenting microbial growth were transferred to $100 \mathrm{~mL}$ Kauffman tetrathionate and selenite cystine broths, respectively, and incubated for $24 \mathrm{~h}$ at $37^{\circ} \mathrm{C}$. After this, the bacterial cultures were streaked onto selective and indicator media, represented by EMB agar, SS agar, and Hektoen enteric agar (all from Difco company), and incubated at $37^{\circ} \mathrm{C}$ for $18 \mathrm{~h}$.

The $\mathrm{pH}$ was measured using a Testo 205 digital $\mathrm{pH}$ meter coupled to a penetration electrode at 45 min and $24 \mathrm{~h}$ after slaughter. The muscle color was evaluated 30 min after being sectioned for the exposure of myoglobin to oxygen, according to the method of Cañeque and Sañudo (2000), using a Minolta CR-400 colorimeter to determine the following coordinates: L* (lightness), a* (red intensity), and $\mathrm{b}^{*}$ (yellow intensity), evaluated by the CIE L* a* b* color system (CIE, 2004). pH and color were evaluated in three different points of the muscle to calculate the average.

To evaluate the $\mathrm{WHC}$, the protocol described by Hamm (1986) was used, according to which meat samples of $500 \pm 20 \mathrm{mg}$ were placed on filter paper with the fibers in the transverse direction and a 10 $\mathrm{kg}$ weight was placed upon them for five minutes. Thereafter, the samples were weighed and the retained water was calculated by subtraction from the initial sample weight. Results were expressed as a percentage of the retained water relative to the initial weight of the sample.

The CL was calculated after weighing and cooking the samples in a $1100 \mathrm{~W}$ George Foreman ${ }^{\circledR}$ electric grill pre-heated for $10 \mathrm{~min}$. Samples were roasted for approximately $10 \mathrm{~min}$ and monitored using a stick digital thermometer until they reached an internal temperature of $71{ }^{\circ} \mathrm{C}$ in their geometric center. Afterwards, samples were removed from the grill and, after reaching room temperature, weighed again to calculate CL.

Subsequently, $1.27 \mathrm{~cm}$ diameter cylinders were removed from the samples using a punch parallel to the direction of muscle fibers (WHEELER et al., 2005), to determine the shear force (SF), using a texture analyzer (Brookfield, CT3 10K) coupled to a Warner-Bratzler blade of $1.016 \mathrm{~mm}$ thickness. Values were expressed in $\mathrm{N}(\mathrm{kgf} \times 9.80665)$.

The obtained data were checked for data analysis assumptions (normality of residues and homogeneity of variances) using the PROC UNIVARIATE procedure. The data were analyzed by the PROC MIXED procedure at the 5\% significance level $(\mathrm{P}<0.05)$, and Tukey's test was used to differentiate the means at a significance level of $5 \%(\mathrm{P}<0.05)$. All procedures were performed using the SAS statistical 
program (Statistical Analysis System, version 9.0), following the mathematical model specified below:

$$
\mathrm{Y}_{\mathrm{ijk}}=\mu+\mathrm{D}_{\mathrm{j}}+\mathrm{DA}_{\mathrm{i}}+(\mathrm{D} \times \mathrm{DA})_{\mathrm{ij}}+\mathrm{e}_{\mathrm{ijk}},
$$

in which $\mathrm{Y}_{\mathrm{ijk}}=$ observed value of the variable that represents days of aging $\mathrm{i}$, diet $\mathrm{j}$, and replicate $\mathrm{k} ; \mu=$ overall mean; $\mathrm{D}_{\mathrm{j}}=$ diet $\mathrm{j}$, ranging from 1 to 4 (forage + concentrate; forage + concentrate $+20 \%$ peanut meal; forage + concentrate $+25 \%$ glycerin; and forage + concentrate $+10 \%$ peanut meal $+12.5 \%$ crude glycerin); $\mathrm{DA}_{\mathrm{i}}=$ days of aging $\mathrm{i}$, from 1 to 2 (0 and 14 days of aging of the semimembranosus muscle); $(\mathrm{D} \times \mathrm{DA})_{\mathrm{ij}}=$ interaction effect between days of aging $\mathrm{i}$ and diet $\mathrm{j}$; and $\mathrm{e}_{\mathrm{ijk}}=$ random error associated with each observation.

\section{Results}

The observed DM intake $(\mathrm{P}>0.05)$ was 0.69 , $0.68,0.70$, and $0.72 \mathrm{~g}$ per day, while fat thickness ( $\mathrm{P}>0.05$ ) was $2.52,2.14,2.91$, and $2.30 \mathrm{~mm}$, for the treatments studied respectively.

Diets and aging did not influence the counts of total coliforms (TC), thermotolerant coliforms (FC), or coagulase-positive Staphylococcus (SC). Salmonella spp. was not detected (Table 2). An interaction was observed $(\mathrm{P}<0.05)$ between diet and aging for $\mathrm{pH}$, color, $\mathrm{CL}$, and $\mathrm{SF}$. This was not observed $(\mathrm{P}>0.05)$ for WHC (Table 3).

Table 2. Microbiological quality of fresh and aged semimembranosus muscle of Ile de France lambs fed peanut meal and glycerin.

\begin{tabular}{|c|c|c|c|c|c|}
\hline \multirow{2}{*}{ Variable } & \multirow{2}{*}{ Days of aging } & \multicolumn{4}{|c|}{ Experimental diet } \\
\hline & & $\mathrm{C}$ & PM & G & PMG \\
\hline \multirow[t]{2}{*}{ TC (MPN/g) } & 0 & $<3.00$ & $<3.00$ & $<3.00$ & $<3.00$ \\
\hline & 14 & $<3.00$ & $<3.00$ & $<3.00$ & $<3.00$ \\
\hline \multirow[t]{2}{*}{$\mathrm{FC}(\mathrm{MPN} / \mathrm{g})$} & 0 & $<3.00$ & $<3.00$ & $<3.00$ & $<3.00$ \\
\hline & 14 & $<3.00$ & $<3.00$ & $<3.00$ & $<3.00$ \\
\hline \multirow[t]{2}{*}{$\mathrm{SC}(\mathrm{cfu} / \mathrm{g})$} & 0 & $<1.0 \times 10^{2}$ & $<1.0 \times 10^{2}$ & $<1.0 \times 10^{2}$ & $<1.0 \times 10^{2}$ \\
\hline & 14 & $<1.0 \times 10^{2}$ & $<1.0 \times 10^{2}$ & $<1.0 \times 10^{2}$ & $<1.0 \times 10^{2}$ \\
\hline \multirow[t]{2}{*}{ Salmonella spp } & 0 & Absence in $25 \mathrm{~g}$ & Absence in $25 \mathrm{~g}$ & Absence in $25 \mathrm{~g}$ & Absence in $25 \mathrm{~g}$ \\
\hline & 14 & Absence in $25 \mathrm{~g}$ & Absence in $25 \mathrm{~g}$ & Absence in $25 \mathrm{~g}$ & Absence in $25 \mathrm{~g}$ \\
\hline
\end{tabular}

$\mathrm{C}$ - roughage + standard concentrate; $\mathrm{PM}$ - roughage + concentrate with $20 \%$ peanut meal; G - roughage + concentrate with $25 \%$ glycerin; PMG - roughage + concentrate with 10\% peanut meal and 12.5\% glycerin, (inclusion percentages on a dry-matter basis). TC - total coliforms MPN - most probable number; FC - fecal or thermotolerant coliforms; SC - coagulase-positive staphylococcus; cfu - colony forming units. 
Table 3. Physical and chemical characteristics of fresh and aged semimembranosus muscle, of Ile de France lambs fed peanut meal and glycerin.

\begin{tabular}{|c|c|c|c|c|c|c|c|c|c|c|}
\hline \multirow{2}{*}{ Variable } & \multicolumn{4}{|c|}{ Experimental diet } & \multicolumn{2}{|c|}{ Days of aging } & \multirow{2}{*}{ SEM } & \multicolumn{3}{|c|}{ P-value } \\
\hline & $\mathrm{C}$ & PM & $\mathrm{G}$ & PMG & 0 & 14 & & $\mathrm{D}$ & A & DxA \\
\hline $\mathrm{pH}$ & 5.57 & 5.56 & 5.55 & 5.55 & 5.66 & 5.45 & 0.018 & 0.5314 & $<0.0001$ & 0.0389 \\
\hline $\mathrm{L}^{*}$ & 39.48 & 38.43 & 40.21 & 38.45 & 37.63 & 40.87 & 0.350 & 0.0019 & $<0.0001$ & 0.0376 \\
\hline$a^{*}$ & 15.72 & 15.82 & 15.32 & 15.31 & 15.12 & 15.93 & 0.134 & 0.0628 & $<0.0001$ & 0.0004 \\
\hline$b^{*}$ & 3.09 & 3.26 & 2.70 & 2.70 & 2.48 & 3.42 & 0.120 & 0.0088 & $<0.0001$ & 0.0008 \\
\hline WHC (\%) & 60.77 & 60.00 & 60.18 & 60.50 & 61.85 & 58.87 & 0.285 & 0.3059 & $<0.0001$ & 0.1681 \\
\hline CL $(\%)$ & 28.46 & 27.50 & 27.91 & 30.17 & 23.84 & 32.59 & 0.770 & 0.0500 & $<0.0001$ & 0.0154 \\
\hline $\mathrm{SF}(\mathrm{N})$ & 18.54 & 20.10 & 20.70 & 19.78 & 22.60 & 16.95 & 0.532 & 0.0069 & $<0.0001$ & 0.0111 \\
\hline
\end{tabular}

Means in the same row followed by different lowercase letters differ by Tukey's test $(\mathrm{P}<0.05)$ for the diet effect. Means in the same column followed by different uppercase letters differ by Tukey's test $(\mathrm{P}<0.05)$ for the effect of aging time.

$\mathrm{C}$ - roughage + standard concentrate; PM - roughage + concentrate with $20 \%$ peanut meal; G - roughage + concentrate with $25 \%$ glycerin; PMG - roughage + concentrate with $10 \%$ peanut meal and $12.5 \%$ glycerin, (inclusion percentages on a dry-matter basis). D - diet; A - aging; SEM - standard error of the mean; L*- lightness; $a^{*}$ - red intensity; $b^{*}$ - yellow intensity;

WHC - water holding capacity; CL - cooking weight loss; SF - shear force.

The decomposition of the interactions (Table 4) revealed that aging influenced $(\mathrm{P}<0.05)$ the $\mathrm{pH}$ of all meats. There was no influence of by-product inclusion $(\mathrm{P}>0.05)$ on the fresh meat $\mathrm{pH}$ values, while for aged meat, the $\mathrm{pH}$ of the meat of the animals fed with the $\mathrm{G}$ diet was higher than those fed with PMG, the other treatments were similar.

In the decomposition of the interactions it was observed that aging promoted increase $(\mathrm{P}<0.05)$ in the luminosity of the meat of the animals fed diets C, PM and G. In the fresh meat it was observed that the originated from the treatments with peanut meal (PM and PMG) were darker, that is to say with a lower value of $\mathrm{L} *$ in relation to the meat originated from the treatment $\mathrm{G}$. In the aged meat the value of $L^{*}$ was higher in $\mathrm{G}$ compared to $\mathrm{PMG}$, the other treatments were similar.

Table 4. $\mathrm{pH}$ and color ( $\mathrm{L}^{*}, \mathrm{a}^{*}$ and $\mathrm{b}^{*}$ ) of fresh and aged semimembranosus muscle of Ile de France lambs fed peanut meal and glycerin and decomposition of the interactions between diet and aging.

\begin{tabular}{|c|c|c|c|c|c|c|}
\hline \multirow{2}{*}{ Days of aging } & \multicolumn{4}{|c|}{ Experimental diet } & \multirow{2}{*}{ SEM } & \multirow{2}{*}{ P-value Diet } \\
\hline & $\mathrm{C}$ & PM & G & PMG & & \\
\hline \multicolumn{7}{|c|}{$\mathrm{pH}$} \\
\hline 0 & $5.68 \mathrm{~A}$ & $5.67 \mathrm{~A}$ & $5.62 \mathrm{~A}$ & $5.67 \mathrm{~A}$ & 0.011 & 0.309 \\
\hline 14 & $5.46 \mathrm{abB}$ & 5.44abB & $5.48 \mathrm{aB}$ & $5.42 \mathrm{bB}$ & 0.007 & 0.022 \\
\hline P-value Aging & $<0.0001$ & $<0.0001$ & 0.0014 & $<0.0001$ & - & - \\
\hline \multicolumn{7}{|c|}{$\mathrm{L}^{*}$} \\
\hline 0 & $38.08 \mathrm{abB}$ & $36.26 \mathrm{bB}$ & $38.45 \mathrm{aB}$ & $37.88 b$ & 0.306 & 0.040 \\
\hline 14 & $40.88 \mathrm{abA}$ & $40.60 \mathrm{abA}$ & $42.54 \mathrm{aA}$ & $39.40 \mathrm{~b}$ & 0.323 & 0.008 \\
\hline P-value Aging & 0.0022 & $<0.0001$ & 0.0025 & 0.2506 & - & - \\
\hline
\end{tabular}


continuation

\begin{tabular}{ccccccc}
\hline & & & $\mathrm{a}^{*}$ & & \\
0 & $14.95 \mathrm{~B}$ & $15.09 \mathrm{~B}$ & 15.67 & 14.73 & 15.123 & 0.116 \\
14 & $16.49 \mathrm{aA}$ & $16.55 \mathrm{aA}$ & $15.04 \mathrm{~b}$ & $15.67 \mathrm{ab}$ & 15.935 & 0.001 \\
P-value Aging & 0.0021 & $<0.0001$ & 0.2345 & 0.0758 & - & - \\
\hline & & & $\mathrm{b}^{*}$ & & & 0.092 \\
0 & $2.61 \mathrm{~B}$ & $2.34 \mathrm{~B}$ & 2.70 & $2.21 \mathrm{~B}$ & 0.08 & 0.003 \\
14 & $3.58 \mathrm{abA}$ & $4.17 \mathrm{aA}$ & $2.69 \mathrm{bc}$ & $3.08 \mathrm{bA}$ & 0.17 & - \\
\hline
\end{tabular}

Means in the same row followed by different lowercase letters differ by Tukey's test $(\mathrm{P}<0.05)$ for the diet effect. Means in the same column followed by different uppercase letters differ by Tukey's test $(\mathrm{P}<0.05)$ for the effect of aging time.

$\mathrm{C}$ - roughage + standard concentrate; PM - roughage + concentrate with $20 \%$ peanut meal; G - roughage + concentrate with $25 \%$ glycerin; PMG - roughage + concentrate with $10 \%$ peanut meal and $12.5 \%$ glycerin, (inclusion percentages on a dry-matter basis). A - aging; SEM - standard error of the mean; L*- lightness; $a^{*}$ - red intensity; $b^{*}$ - yellow intensity.

The diets only influenced the $\mathrm{a}^{*}$ values in the aged meat, the meats from animals fed diet $\mathrm{G}$ presenting the lowest values in relation to $\mathrm{C}$ and $\mathrm{PM}, \mathrm{PMG}$ was similar to the others. Red intensity was higher in aged compared with fresh meat, but only for the meats from animals fed $\mathrm{C}$ diets and PM. The color coordinate $\mathrm{b}^{*}$ was influenced by diet in aged meats, and the highest value was observed for meat from animals fed $\operatorname{diet} \mathrm{PM}$, which in turn was similar to $C$. The values of $b^{*}$ were higher $(\mathrm{P}<0.05)$ for aged meats, with the exception of meats originating from animals fed the $\mathrm{G}$ diet.
After aging, WHC declined from 61.85 to $58.87 \%(\mathrm{P}<0.05)$, but there was no interaction effect $(\mathrm{P}>0.05)$ between diet and aging for this variable. $\mathrm{CL}$ was higher in the aged meat $(\mathrm{P}<0.05)$. In the decomposition of the interactions (Table 5), there was no difference in SF for fresh meat $(\mathrm{P}>0.05)$, while an influence of diet was observed on the aged meats $(\mathrm{P}<0.05)$; the meat from animals fed control diet was the tenderest. Aging promoted a reduction $(\mathrm{P}<0.05)$ in $\mathrm{SF}$.

Table 5. Cooking weight loss and shear force of fresh and aged semimembranosus muscle of Ile de France lambs fed peanut meal and glycerin and decomposition of the interactions between diet and aging.

\begin{tabular}{|c|c|c|c|c|c|c|}
\hline \multirow{2}{*}{ Days of aging } & \multicolumn{4}{|c|}{ Experimental diet } & \multirow{2}{*}{ SEM } & \multirow{2}{*}{$\begin{array}{c}\text { P-value } \\
\text { Diet }\end{array}$} \\
\hline & $\mathrm{C}$ & PM & G & PMG & & \\
\hline \multicolumn{7}{|c|}{ CL (\%) } \\
\hline 0 & 24.84B & 23.01B & $23.85 \mathrm{~B}$ & $23.38 \mathrm{~B}$ & 0.278 & 0.060 \\
\hline 14 & $32.08 \mathrm{bA}$ & $32.00 \mathrm{bcA}$ & $32.98 \mathrm{abA}$ & $33.56 \mathrm{aA}$ & 0.218 & 0.016 \\
\hline P-value Aging & $<0.0001$ & $<0.0001$ & $<0.0001$ & 0.0003 & - & - \\
\hline \multicolumn{7}{|c|}{$\mathrm{SF}(\mathrm{N})$} \\
\hline 0 & $22.03 \mathrm{~A}$ & $21.82 \mathrm{~A}$ & $23.95 \mathrm{~A}$ & $22.61 \mathrm{~A}$ & 0.359 & 0.226 \\
\hline 14 & $15.05 \mathrm{cB}$ & $18.38 \mathrm{aB}$ & $17.44 \mathrm{abB}$ & $16.95 \mathrm{bB}$ & 0.342 & $<0.0001$ \\
\hline P-value Aging & 0.0003 & $<0.0001$ & 0.0007 & 0.0053 & - & - \\
\hline
\end{tabular}

Means in the same row followed by different lowercase letters differ by Tukey's test $(\mathrm{P}<0.05)$ for the diet effect. Means in the same column followed by different uppercase letters differ by Tukey's test $(\mathrm{P}<0.05)$ for the effect of aging time.

$\mathrm{C}$ - roughage + standard concentrate; PM - roughage + concentrate with $20 \%$ peanut meal; G - roughage + concentrate with $25 \%$ glycerin; PMG - roughage + concentrate with $10 \%$ peanut meal and $12.5 \%$ glycerin, (inclusion percentages on a dry-matter basis). A - aging; SEM - standard error of the mean; CL - cooking weight loss; SF - shear force; .N - Newton, 


\section{Discussion}

The Brazilian legislation (BRASIL, 2001), establishes the values of $10^{4}$ most probable number/g (MPN $\mathrm{g}^{-1}$ ) for $\mathrm{FC}$ and $3 \times 10^{3}$ colony forming units $\mathrm{g}\left(\mathrm{cfu}^{-1}\right)$ for $\mathrm{SC}$ as acceptable microbiological standards for the consumption of vacuum-packed fresh meat. For vacuum-packaged aged meats, however, the microbiological standards are $5 \times 10^{3}\left(\mathrm{MPN} \mathrm{g}^{-1}\right)$ for $\mathrm{FC}$ and $3 \times 10^{3}\left(\mathrm{cfu} \mathrm{g}^{-1}\right)$ for $\mathrm{SC}$. For TC, there is no minimum requirement, and Salmonella spp. should be absent.

The obtained results showed that the analyzed meat meets the microbiological requirements for consumption, demonstrating that health standards for food handling were respected, since the microorganism count is used as an indicator of meat hygienic quality and may also provide information about the shelf life. According to Marques et al. (2006), meat products may pose significant risks to public health when Salmonella spp. is present, as these bacteria are common causes of foodborne diseases.

The $\mathrm{pH}$ values of the meats observed in this study are close to normal for sheep meat according to Silva Sobrinho et al. (2005), who reported 5.5 to 5.8 as normal values for the final $\mathrm{pH}$. The lowest $\mathrm{pH}$ was observed in aged meats.

As stated by Constantino et al. (2012), when the $\mathrm{pH}$ is low, the myofibrillar proteins are at their isoelectric point, which means that they have a similar amount of positive and negative charges and cannot bind to the water, thus moving to the surface and reflecting the light. This results in higher lightness values, as observed in the present study. Lage et al. (2014) did not observe differences in the $\mathrm{pH}$ value of the longissimus muscle of lambs fed diets containing up to $32 \%$ glycerol, with $\mathrm{pH}$ values ranging from 6.0 to 6.1 .

The increase in lightness after aging can be explained by the decrease in WHC and the increase in CL, because some of these parameters may be associated with the integrity of the membranes and the higher loss of liquid to extracelluar environment, considering that proteolysis begins $24 \mathrm{~h}$ after death (KOOHMARAIE, 2002). According to Sañudo et al. (2000), for sheep meat, variations from 30.03 to 49.47 for $\mathrm{L}^{*}, 8.24$ to 23.53 for $\mathrm{a}^{*}$, and 3.38 to 11.10 for $b^{*}$ are reported, while the values obtained in this study were 36.26 to 42.54 for $\mathrm{L}^{*}$ and 14.73 to 16.55 for $\mathrm{a}^{*}$, considered within the normal range. For the $b^{*}$ variable (2.21 to 4.17), the lowest observed value was slightly lower than those considered normal.

Longer aging periods accelerate the meat blooming process, considering that, over time, oxygen becomes more available for transformation into oxymyoglobin, due to the reduction of enzymes competing for oxygen (OLIETE et al., 2006). According to those authors, the increase in $b^{*}$ during aging is a result of oxidation of the oxymyoglobin pigment to methemoglobin, the brown pigment.

Civit et al. (2014) studied the effect of aging on the quality of meat from Corriedale cull ewes and observed an increase in $L^{*}$ (30.6 to 32.8), a* (14.7 to 17.2 ), and $b^{*}$ (6.3 to 7.8 ) values from one to 14 days of aging, respectively. Pinheiro et al. (2009) reported $\mathrm{L}^{*}, \mathrm{a}^{*}$, and $\mathrm{b}^{*}$ values of $40.10,14.10$, and 2.61 , respectively, in the semimembranosus muscle of lambs.

Despite being slightly above the others, the $L^{*}$ values of meat from animals fed diet $\mathrm{G}$ are within the normal limits for sheep meat, ranging from 30.03 to 49.47 according to Sañudo et al. (2000). The decrease in WHC after aging can be caused by the proteolysis occurring during this process, since protein degradation changes the interfibrillar spaces, triggering changes in the structures of muscle tissues and reducing the holding water capacity of the meat. According to Lawrie (2005), $\mathrm{pH}$ values below 5.0-5.5 result in higher WHC, as this $\mathrm{pH}$ range characterizes the isoelectric point of many muscle proteins, including myofibrils.

Silva Sobrinho et al. (2005) also observed that fresh semimembranosus muscle had higher WHC 
(73.10\%) than those aged for 14 days $(62.9 \%)$. This qualitative characteristic influences the sensory attributes and commercial value of the meat and also its nutritional quality, since the released exudate carries vitamins, minerals, amino acids, and other nutrients (SILVA SOBRINHO, 2001).

The decline in CL with aging can also be explained by the disruption of cell membranes during proteolysis. With similar results to those of this study, Fernandes et al. (2012) observed a linear increase in CL during the storage of the longissimus muscle of sheep, which rose from $18.24 \%$ on the first day to $28.25 \%$ at the 28 th day of aging. The authors stated that this increase in CL was probably due to the proteolytic activity caused by the endopeptidases of the meat itself and by enzymes produced by microorganisms.

The influence of the diets on the SF values of aged meat was an unexpected pattern because, according to Pardi et al. (2001), tenderness attributes are closely related to $\mathrm{WHC}, \mathrm{pH}$, fatness, and characteristics of connective tissue and muscle fiber.

In this study, the $\mathrm{pH}$ and $\mathrm{WHC}$ of the meat from animals fed control diet did not differ from the other treatments, and the type of fiber analyzed was the same for all animals. According to the literature, the by-products used in this study do not promote changes in the SF of sheep and beef meat (LAGE et al., 2014; CARVALHO et al., 2015; BEZERRA et al., 2016; BORGHI et al., 2016), reinforcing the unexpected pattern of SF in this work.

The SF values observed for fresh meat allow them to be classified as tender or of medium tenderness, whereas for the aged meat, all values for this variable denoted it as tender. According to Cezar and Sousa (2007), sheep meat can be classified as tender when presenting a SF lower than $22.26 \mathrm{~N}$; of medium tenderness with SF from 22.26 to $35.60 \mathrm{~N}$; tough when $\mathrm{SF}$ is higher than $35.60 \mathrm{~N}$; and extremely tough when SF values are higher than $53.35 \mathrm{~N}$.
During the aging process, the meat tenderness increases as a result of the action of calpains, enzymes that act by degrading the myofibrillar proteins in internal points of the molecules (ANDRIGHETTO et al., 2006).

\section{Conclusions}

The by-products from biodiesel and peanut production can fully and simultaneously replace corn and soybean meal without interfering with the developmentofmicroorganisms inmeatornegatively affecting its physicochemical characteristics. Aging does not promote the proliferation of pathogenic microorganisms but rather improves the tenderness of lamb meat.

\section{References}

ALETOR, O.; OJELABI, A. Comparative evaluation of the nutritive and functional attributes of some traditional Nigerian snacks and oil seed cakes. Pakistan Journal of Nutrition, v. 6, n. 1, p. 99-103, 2007. DOI: 10.3923/ pjn.2007.99.103

ANDRIGHETTO, C.; JORGE, A. M.; ROÇA, R. O.; ROCHA SARTORI, D.; RODRIGUES, E.; BIANCHINI, W. Maturação da carne bovina (Ageing of meat beef). Revista Electrónica de Veterinária, Málaga, v. 7, n. 6, p. 1-6, 2006.

ASSOCIATION OF OFFICIAL ANALYTICAL CHEMISTS - AOAC. Official methods of analysis. $15^{\text {th }}$ ed. Arlington: Edited by Kenneth Helrich, 1990. v. 1-2, $1298 \mathrm{p}$.

ASSOCIATION OF OFFICIAL ANALYTICAL CHEMISTS - AOAC. Official methods of analysis. $16^{\text {th }}$ ed. Gaithersburg: Edited by Kenneth Helrich, 1995.

BAWCOM, D. W.; THOMPSON, L. D.; MILLER, M. F.; RAMSE, C.B. Reduction of microorganisms on beef surfaces utilizing electricity. Journal of Food Protection, Des Moines, v. 58, n. 1, p. 35-38. 1995. DOI: 10.4315/0362-028X-58.1.35

BEZERRA, L. S.; BARBOSA, A. M.; CARVALHO, G. G. P.; SIMIONATO, J. I.; FREITAS, J. E.; ARAÚJO, M. L. G. M. L.; CARVALHO, B. M. A. Meat quality of lambs fed diets with peanut cake. Meat Science, Cowra, v. 121, n. 1, p. 88-95, 2016. DOI: 10.1016/j.meatsci.2016.05.019 
BORGHI, T. H.; SILVA SOBRINHO, A. G. D.; ZEOLA, N. M. B. L.; ALMEIDA, F. A. D.; CIRNE, L. G. A.; LIMA, A. R. C. Dietary glycerin does not affect meat quality of Ile de France lambs. Revista Brasileira de Zootecnia, Viçosa, MG, v. 45, n. 9, p. 554-562, 2016. DOI: $10.1590 / \mathrm{S} 1806-92902016000900008$

BRASIL. Resolução RDC n 12 , de 02 de janeiro de 2001. Aprova o regulamento técnico sobre padrões microbiológicos para alimentos. Diário Oficial [da] República Federativa do Brasil, v. 139, n. 7-E, p. 1-48, 2001.

CAÑEQUE, V.; SAÑUDO, C. Metodologia para el estudo de la calidad de la canal y de la carne en rumiantes. Monografías INIA, Ganadera n. 1. Ministerio de Ciencia y Tecnología, Madrid. 2000. 255 p.

CARVALHO, V. B.; LEITE, R. F.; ALMEIDA, M. T. C.; PASCHOALOTO, J. R.; CARVALHO, E. B.; LANNA, D. P. D.; EZEQUIEL, J. M. B. Carcass characteristics and meat quality of lambs fed high concentrations of crude glycerin in low-starch diets. Meat Science, Cowra, v. 110, n. 1, p. 285-292, 2015. DOI:10.1016/j. meatsci.2015.08.001

CEZAR, M. F.; SOUSA, W. H. Carcaças ovinas e caprinas: obtenção-avaliação-classificação. Uberaba: Agropecuária Tropical, 2007. 131 p.

CIE. International Comission on Illumination. Colorimetry: Technical Report. Central Bureau of the CIE; 2004.

CIVIT, D.; DÍAZ, M. D.; RODRÍGUEZ, E.; GONZÁlEZ, C. A. Características de la canal y efecto de la maduración sobre la calidad de la carne de ovejas de desvieje de raza Corriedale. ITEA, Buenos Aires, v. 110, n. 2, p. 160-170, 2014. DOI: 10.12706/itea.2014.010

CONSTANTINO, C.; RIBEIRO, E. L. A.; BRIDI, A. M.; TARSITANO, M.; KORITIAKI, N. A.; PERES, L. M.; MIZUBUTI, I. Y.; PEREIRA, E. S.; PIMENTEL, P. G. Quality of aged ewe meat in vacuum-packaging system for different storage periods. Semina: Ciências Agrárias, Londrina, v. 33, n. 2, p. 3437-3446, 2012. DOI: 10.5433/1679-0359.2012v33Supl2p3437

DASARI, M. A.; KIATSIMKUL, P. P.; SUTTERLIN, W. R.; SUPPES, G. J. Low-pressure hydrogenolysis of glycerol to propylene glycol. Applied Catalysis A: General, Evanston, v. 28, n. 1, p. 225-231, 2005. DOI: 10.1016/j.apcata.2004.11.033

FÁVARO, V. R.; EZEQUIEL, J. M. B.; ALMEIDA, M. T. C.; D'AUREA, A. P.; PASCHOALOTO, J. R.; VAN CLEEF, E. H. C. B.; CARVALHO, V. B.; JUNQUEIRA, N. B. Carcass traits and meat quality of Nellore cattle fed different non-fiber carbohydrates sources associated with crude glycerin. Animal, Cambridge, v. 10, n. 8, p. 14021408, 2016. DOI: 10.1017/S1751731116000094

FERNANDES, R. P. P.; FREIRE, M. T. A.; CARRER, C. C.; BALIEIRO, J. C. C.; TRINDADE, M. A. Estabilidade físico-química, microbiológica e sensorial de carne ovina embalada a vácuo estocada sob refrigeração. Ciência Rural, Santa Maria, v. 42, n. 4, p.724-729, 2012. DOI: 10.1590/S0103-84782012000400025

HAMM, R. Functional properties of the myofibrillar system and their measurements. In: BECHTEL, P. J. (Ed.). Muscle as food. New York: Academic Press Inc., 1986. p. 135-199.

JOHNSON, D. T.; TACONI, K. A. The glycerin glut: Options for the value $\square$ added conversion of crude glycerol resulting from biodiesel production. Environmental Progress, Toronto, v. 26, n. 4, p. 338-348, 2007. DOI: 10.1002/ep. 10225

KOOHMARAIE, M.; KENT, M. P.; SHACKEIFORD, S. D.; EVA VEISETH, E.; WHEELER, T. L. Meat tenderness and muscle growth: is there any relationship? Meat Science, Cowra, v. 62, n. 3, p. 345-352, 2002. DOI: 10.1016/S0309-1740(02)00127-4

LAGE, J. F.; PAUlinO, P. V. R.; PEREIRA, L. G. R.; DUARTE, M. S.; VALADARES FILHO, S. C.; OLIVEIRA, A. S.; SOUZA, N. K. P.; LIMA, J. C. M. Carcass characteristics of feedlot lambs fed crude glycerin contaminated with high concentrations of crude fat. Meat Science, Cowra, v. 96, n. 1, p. 108-113, 2014. DOI: 10.1016/j.meatsci.2013.06.020

LAWRIE, R. A. Ciência da carne. 6. ed. Porto Alegre: Artmed, 2005. 384 p.

MARQUES, S. C.; BOARI, C. A.; BROKO, C. C.; NASCIMENTO, A. R.; PICCOLI, R. H. Avaliação higiênico-sanitária de linguiças tipo frescal comercializadas nos municípios de Três Corações e Lavras - MG. Ciência e Agrotecnologia, Lavras, v. 30, n. 6, p. 1120-1123, 2006. DOI: 10.1590/S141370542006000600012

NATIONAL RESEARCH COUNCIL - NRC. Nutrient requeriments of small ruminants: sheep, goats, cervids and New World camelids. Washington: National Academies Press, 2007.

OLIETE, B.; CARBALLO, J. A.; VARELA, A.; MORENO, T.; MONSERRAT, L.; SÁNCHEZ, L. Effect of weaning status and storage time under vacuum upon physical characteristics of meat of the Rubia Gallega breed. Meat Science, Cowra, v. 73, n. 1, p. 102-108, 2006. DOI: $10.1016 /$ j.meatsci.2005.11.004 
PARDI, M. C.; SANTOS, I. F.; SOUZA, E. R.; PARDI, H. S. Ciência, higiene e tecnologia da carne. 2. ed. Goiânia: UFG, 2001. 520 p.

PINHEIRO, R. S. B.; SILVA SOBRINHO, A. G. D.; SOUZA, H. B. A. D.; YAMAMOTO, S. M. Qualidade de carnes provenientes de cortes da carcaça de cordeiros e de ovinos adultos. Revista Brasileira de Zootecnia, Viçosa, MG, v.38, n. 9, p. 1790-1796, 2009. DOI: 10.1590/S1516-35982009000900022

SAÑUDO, C.; ENSER, M. E.; CAMPO, M. M.; NUTE, G. R.; MARÍA, G.; SIERRA, I. E.; WOOD, J. D. Fatty acid composition and sensory characteristics of lamb carcasses from Britain and Spain. Meat Science, Cowra, v. 54 , n. 4 , p. $339-346,2000$. DOI: 10.1016/S03091740(99)00108-4

SILVA SOBRINHO, A. G. Criação de ovinos. 2. ed. Jaboticabal: FUNEP, 2001. 302 p.

SILVA SOBRINHO, A. G.; PURCHAS, R. W.; KADIM, I. T.; YAMAMOTO, S. M. Características de qualidade da carne de ovinos de diferentes genótipos e idades ao abate. Revista Brasileira de Zootecnia, Viçosa, MG, v. 34 , n. 3 , p. $1070-1078,2005$. DOI: $10.1590 /$ S151635982005000300040
SILVA, T. M.; OLIVEIRA，R. L.; NASCIMENTO JÚNIOR, N. G.; PELLEGRINI, C. B.; TRAJANO, J. S.; ROCHA, T. C.; BORJA, M. S. Ingestive behavior and physiological parameters of goats fed diets containing peanut cake from biodiesel. Tropical Animal Health and Production, Edinburgh, v. 48, n. 1, p. 59-66, 2016. DOI: 10.1007/s11250-015-0920-6

SNIFFEN, C. J.; O'CONNOR, J. D.; VAN SOEST, P. J.; FOX, D.G.; RUSSELL, J. B. A net carbohydrate and protein system for evaluating cattle diets. II. Carbohydrate and protein availability. Journal of Animal Science, Oxford, v. 70, n. 11, p. 3562-3577, 1992. DOI: 10.2527/1992.70113562x

VAN SOEST, P. J.; ROBERTSON, J. B.; LEWIS, B. A. Methods for dietary fiber, neutral detergent fiber, and nonstarch polysaccharides in relation to animal nutrition. Journal of Dairy Science, Illinois, v. 74, n. 10 , p. $3583-3597,1991$. DOI: $10.3168 /$ jds.S00220302(91)78551-2

WHEELER, T. L.; SHACKELFORD, S. D.; KOOHMARAIE, M. Shear force procedures for meat tenderness measurement. Meat Animal Research Center: United States Department of Agriculture, 2005. 7 p. 